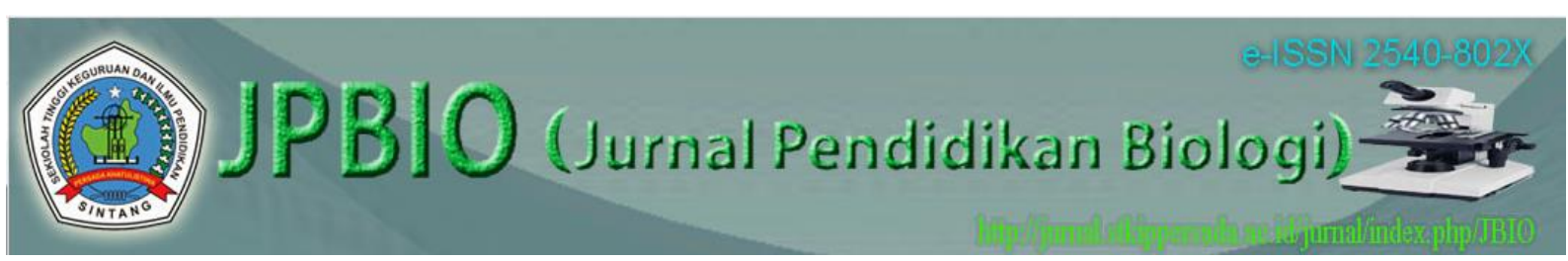

JPBIO (Jurnal Pendidikan Biologi)

Vol. 3 No. 1 April 2018 | $26-32$

ISSN 2540-802x (Online)

DOI: http://dx.doi.org/10.31932/ JPBIO (Jurnal Pendidikan Biologi)

http://jurnal.stkippersada.ac.id/jurnal/index.php/JBIO

\title{
PENGARUH METODE GUIDED NOTE TAKING BERBANTUAN MEDIA GAMBAR TERHADAP HASIL BELAJAR SISWA PADA MATERI SISTEM PEREDARAN DARAH PADA MANUSIA
}

\author{
Fransiska Riska $^{1 *}$, Didin Syafruddin ${ }^{2}$, Yasinta Lisa $^{3}$ \\ ${ }^{1}$ Mahasiswa Program Studi Pendidikan Biologi, STKIP Persada Khatulistiwa, Sintang \\ 2,3Dosen Program Studi Pendidikan Biologi, STKIP Persada Khatulistiwa, Sintang \\ E-mail: rfransiska244@gmail.com ${ }^{1}$, didin_saprudin28@yahoo.com ${ }^{2 *}$, \\ yasintalisa@gmail.com ${ }^{3}$
}

Diterima: 20 Januari 2018

Direvisi: 15 Februari 2018

Disetujui: 21 Maret 2018

\begin{abstract}
ABSTRAK
Tujuan penelitian ini untuk mengetahui pengaruh metode guided note taking berbantuan media gambar terhadap hasil belajar siswa pada materi sistem peredaran darah pada manusia, metode penelitian yang digunakan adalah penelitian eksperimen yakni quasy eksperimental design yang menggunakan desain penelitian nonequivalent control group design. Teknik pengumpulan data dengan menggunakan teknik observasi langsung, teknik pengukuran, dan teknik komunikasi tidak langsung, alat pengumpulan data berupa lembar observasi, soal tes, dan angket. setelah dilakukan analisis diketahui bahwa metode guided note taking berbantuan media gambar berpengaruh secara signifikan terhadap hasil belajar siswa, hal ini ditunjukan dengan data pretest dan posttest kelas eksperimen yang dihitung menggunakan spss 23.0 dengan nilai sig. (2-tailed) sebesar 0,000 dan hal ini kurang dari $0,025(0,000<0,025)$ sehingga dapat disimpulkan bahwa Ha di terima dan $\mathrm{HO}$ ditolak, hal ini dapat disimpulkan bahwa terdapat pengaruh yang signifikan metode guided note taking berbantuan media gambar terhadap hasil belajar siswa pada materi sistem peredaran darah pada manusia.
\end{abstract}

Kata kunci: guided note taking, media gambar, hasil belajar

\section{ABSTRACT}

The purpose of this study to determine the effect of guided note taking method assisted media images on student learning outcomes on the circulatory system material in humans, research method used is experimental research quasy experimental design using design research nonequivalent control group design. Data collection techniques using direct observation techniques, measurement techniques, and indirect communication techniques, data collection tools in the form of observation sheets, test questions, and questionnaires. after analysis it is known that guided note taking method with media aided image significantly influence student's learning result, it is shown with pretest and posttest data of experimental class which is calculated using spss 23.0 with sig value. (2-tailed) of 0.000 and this is less 
than $0.025(0.000<0.025)$ so it can be concluded that Ha received and $\mathrm{HO}$ rejected, it can be concluded that there is a significant effect of guided note taking method of image media on student learning outcomes on material circulatory system in humans.

Keywords: guided note taking, visual aid, learning outcome

\section{PENDAHULUAN}

Kegiatan belajar dan mengajar merupakan kegiatan yang paling pokok dari keseluruhan proses pendidikan (Djamarah, 2011). Berhasil atau tidaknya pencapaian tujuan pendidikan tergantung pada bagaimana proses tersebut dirancang dan dijalankan. Pencapaian kualitas belajar mengajar yang optimum merupakan salah satu hal yang sangat diharapkan (Sulistyo, 2011). Keberhasilan pencapaian proses pendidikan terutama ditentukan oleh proses belajar mengajar yang dialami siswa. Siswa dalam belajar diharapkan mampu mengalami perubahan baik dalam aspek kognitif, afektif, dan psikomotorik. Sikapsikap yang harus diambil guru dalam proses pembelajaran hendaknya sesuai dan mampu meningkatkan hasil belajar siswa.

Hasil observasi awal di SMP 3 Silat Hilir adalah proses pembelajaran masih menggunakan metode konvensional, catatan siswa kurang lengkap, media gambar kurang dioptimalkan, pembelajaran kurang menarik minat dan motivasi siswa, serta siswa bersifat pasif, sehingga hasil belajar siswanya tidak memenuhi standar kriteria ketuntasan minimal (KKM) yang sudah ditetapkan dari sekolah yaitu dengan nilai minimun 70 .

Menurut Slameto(2010:54-69) Menyatakan: Hasil belajar dipengaruhi oleh dua faktor yaitu faktor intern dan faktor ekstern. Faktor intern adalah faktor yang berasal dari dalam diri individu yang terdiri atas intelegensi, perhatian, minat bakat, motivasi, kematangan, kesikapan. Sedangkan faktor ekstern adalah faktor yang berasal dari luar diri individu seperti lingkungan keluarga, lingkungan sekolah, dan lingkungan masyarakat.

Hasil belajar sangat penting untuk menambah motivasi siswa, sehingga siswa dapat mengetahui sejauh mana telah berhasil mengikuti pelajaran yang diberikan guru, apakah siswa merasa puas atau tidak puas dengan hasil yang diperolehnya, apabila hasilnya memuaskan akan menyenangkan dan dapat memotivasi siswa untuk belajar lebih giat lagi dan apabila hasil belajar kurang memuaskan maka siswa tersebut akan berusaha untuk meningkatkan hasil belajarnya.

Hasil belajar yang baik dapat tercapai dengan menggunakan suatu metode yang sesuai. Metode yang baik adalah yang disesuaikan dengan materi yang akan disampaikan, kondisi siswa dan sarana yang tersedia. Mengikut sertakan keaktifan siswa dalam proses pembelajaran misalnya, mencatat sangatlah diperlukan. Menulis dan mencatat merupakan kegiatan yang tidak dapat terpisahkan dari aktivitas belajar siswa (Djamarah, 2011).Kegiatan mencatat merupakan aktivitas yang sering dilakukan dalam berbagai jenjang pendidikan, mencatat merupakan salah satu meningkatkan daya ingat. Tujuan mencatat adalah membantu mengingat informasi yang tersimpan di dalam memori, tanpa mencatat dan mengulang informasi, siswa hanya mengingat sebagian kecil materi yang diajarkan (Rostikawati, 2008).

Berdasarkan observasi dan wawancara di Sekolah Menengah Pertama Negeri 3 Silat Hilir pada tanggal 5 Juni 2017, diperoleh permasalahan yang sering terjadi di dalam proses belajar mengajar adalah guru dalam menyampaikan materi masih bersifat konvensional, dimana dalam proses pembelajaran ceramah lebih dominan digunakan daripada memberikan kesempatan kepada siswa untuk menggali sendiri pengetahuannya.Proses yang demikian akan menciptakan rutinitas yang membosankan bagi siswa, siswa cenderung bersifat pasif dalam proses pembelajaran yang berlangsung di dalam kelas, siswa juga akan cenderung mendengarkan penjelasan guru saja. Di dalam proses belajar mengajar, guru kurang mampu menggali pengetahuan siswa, sehingga menyebabkan perhatian siswa kurang aktif dikelas. Hal ini akan berdampak pada hasil belajar siswa. Selain itu dalam proses belajar mengajar guru kerap kali tidak menggunakan media bantu dalam menjelaskan materi sehingga siswa tidak tertantang untuk mengikuti proses belajar mengajar. 
Metode guided note taking atau catatan terbimbing adalah bentuk catatan yang dihasilkan oleh siswa dengan instruksi guru, panduan lengkap berdasarkan topik pembelajaran dimana mengharuskan siswa untuk mengisi konsep-konsep hasil belajar dan kata kunci dalam titik-titik yang dirancang kedalam sebuah catatan oleh guru yang mengajar (Cornelius, 2008). Secara umum langkah pembelajaran guided note taking sebagai berikut: Memberikan bahan ajar berupa handout kepada siswa, materi ajar di sampaikan dengan metode ceramah, Mengosongkan sebagian poin-poin yang penting sehingga terdapat bagian-bagian yang kosong dalam handout tersebut. Beberapa cara yang dapat dilakukan adalah dengan mengosongkan istilah atau definisi, atau menghilangkan beberapa kata kunci, Menjelaskan kepada siswa bahwa bagian yang kosong dalam handout memang sengaja dibuat agar mereka tetap berkonsentrasi mengikuti pembelajaran, Selama ceramah berlangsung siswa diminta untuk mengisi bagian-bagian yang kosong tersebut, Setelah penyampaian materi dengan metode ceramah selesai, guru meminta siswa untuk membacakan handoutnya. Berdasarkan uraian diatas maka peneliti tertarik untuk melakukan penelitian dengan judul "Pengaruh Metode Guided Note Taking Berbantuan Media Gambar Terhadap Hasil Belajar Siswa Materi Sistem Peredaran Darah Pada Manusia Di Kelas VIII Sekolah Menengah Pertama Negeri 3 Silat Hilir".

\section{METODE PENELITIAN}

Pendekatan penelitian yang digunakan dalam penelitian ini adalah kuantitatif dan metode yang digunakan dalam penelitian ini adalah metode eksperimen. Bentuk penelitian yang digunakan dalam penelitian ini yaitu Quasi Exprimental Design dengan rancangan penelitian Nonequivalent Control Group Design. Menurut Sugiyono (2013: 114), "Quasi Experimental Design mempunyai kelompok kontrol, tetapi tidak dapat berfungsi sepenuhnya untuk mengontrol variabel-variabel luar yang mempengaruhi pelaksanaan eksperimen". Sedangkan"Nonequivalent Control Group Design adalah desain yang hampir sama dengan pretest-posttest control group design, hanya pada desain ini kelompok eksperimen maupun kontrol tidak dipilih secara random". Populasi yang digunakan dalam penelitian ini adalah siswa dan siswi kelas VIII yang berjumlah 40 siswa di SMP Negeri 3 Silat Hilir. Pada kelas VIIIB berjumlah 21 siswa, pada kelas VIIIC berjumlah 19 siswa. Adapun teknik sampel yang digunakan dalam penelitian ini adalah seluruh siswa kelas VIII SMP Negeri 3 Silat Hilir Tahun Pelajaran 2017/2018 dengan jumlah siswa sebanyak 63 siswa.

Variabel bebas atau variable independent adalah variabel yang mempengaruhi atau yang menjadi sebab perubahannya atau timbulnya variabel terikat (variable dependent). Variabel bebas dalam penelitian ini adalah metode guided note taking berbantuan media gambar, sedangkan Variabel terikat atau variable dependent adalah variabel yang dipengaruhi atau yang menjadi akibat, karena adanya variabel bebas. Variabel bebas dalam penelitian ini adalah hasil belajar siswa.

Alat pengumpulan data menggunakan a). Lembar observasi, b). Soal tes dan c). Lembar angket. Analisis data menggunakan analisis deskriptif dan inferensial. Analisis inferensial menggunakan Paired Samples Test. Sebelum dilakukan analisis inferensial terlebih dahulu dilakukan uji normalitas dan homogenitas.

\section{HASIL PENELITIAN}

Pretest dilakukan untuk mengetahui kemampuan awal siswa pada materi sistem peredaran darah pada manusia sebelum menggunakan metode Guided Note Taking berbantuan media gambar. Hasil belajar siswa dianalisis dengan cara mengubah skor menjadi nilai. Nilai belajar siswa diperoleh dari skor yang dicapai dibagi skor total kemudian dikalikan nilai maksimal (seratus). Sedangkan posttest dilakukan untuk mengetahui hasil belajar siswa pada materi sistem peredaran darah setelah menggunakan metode guided note taking berbantuan media gambar di kelas eksperimen dan metode konvensional di kelas kontrol. Soal yang digunakan dalam kegiatan posttest adalah soal yang sama dengan soal pretest. Nilai belajar siswa diperoleh dari skor yang dicapai dibagi skor total kemudian dikali nilai maksimal (seratus). Hasil analisis data pretest dan posttest pada kelas eksperimen dan kelas kontrol dapat dilihat pada Tabel.1. 
Tabel. 1. Hasil Pretes Postest Kelas Eksperimen dan Kontrol

\begin{tabular}{ccccc}
\hline \multirow{2}{*}{ Keterangan } & \multicolumn{2}{c}{ Kelas Eksperimen } & \multicolumn{2}{c}{ Kelas Kontrol } \\
\cline { 2 - 5 } & Pretest & Posttest & Pretest & Posttest \\
\hline N & 19 & 19 & 21 & 21 \\
\hline NilaiTertinggi & 60 & 95 & 55 & 85 \\
\hline NilaiTerendah & 10 & 55 & 20 & 50 \\
\hline Nilai Rata-rata & 31,32 & 78,16 & 36,19 & 64,52 \\
\hline Jum. Tuntas & 0 & 17 & 0 & 8 \\
\hline Jum. TidakTuntas & 19 & 2 & 21 & 13 \\
\hline
\end{tabular}

Hasil analisis data posttest kelas eksperimen diperoleh nilai tertinggi 95 dan nilai terendah 55 dengan nilai rata-rata 78,16 dari 19 siswa. Sementara itu, data posttestkelas kontrol nilai tertinggi 85 dan nilai terendah 50 dengan nilai rata-rata 64,52 dari 21 siswa.

Uji normalitas data dilakukan baik untuk data pretest maupun posttest kelas VIII C sebagai kelas eksperimen dan kelas VIII B sebagai kelas kontrol yang dianalisis dengan program SPSS Statistics 23.0. Hasil uji normalitas data dapat dilihat pada Tabel 2.

Tabel .2. Hasil Uji Normalitas Kelas Eksperimen dan Kelas Kontrol

\begin{tabular}{ccccccc}
\hline Ket. & Jenis Test & $\overline{\mathbf{X}}$ & SD & Sig. & $\mathbf{a}$ & Kesimpulan \\
\hline $\begin{array}{c}\text { KelasEksperim } \\
\text { en }\end{array}$ & Pretest & 31,32 & 12,23 & 0,50 & 0,05 & Normal \\
\cline { 2 - 7 } & Posttest & 78,16 & 10,96 & 0,200 & 0,05 & Normal \\
\hline \multirow{2}{*}{ Kelaskontrol } & Pretest & 36,19 & 9,86 & 0,96 & 0,05 & Normal \\
\cline { 2 - 7 } & Posttest & 64,52 & 11,17 & 0,62 & 0,05 & Normal \\
\hline
\end{tabular}

Pengujian hipotesis dilakukan untuk mengambil keputusan hipotesis mana yang akan diterima $\mathrm{H}_{0}$ atau $\mathrm{H}_{\mathrm{a}}$. Setelah dilakukan uji normalitas dan uji homogenitas maka diperoleh data normal dan homogen. Hasil uji hipotesis kelas eksperimen dan kelas kontrol dapat dilihat pada Tabel 4.

Tabel .3. Uji Hipotesis

\begin{tabular}{lccl}
\hline \multicolumn{1}{c}{ Jenis Test } & Sig. (2-tailed) & a & Kesimpulan \\
\hline $\begin{array}{l}\text { Pretest Kelas Eksperimen dan } \\
\text { Kelas Kontrol }\end{array}$ & 0,172 & 0,025 & $\mathrm{H}_{0}$ diterima \\
\hline $\begin{array}{l}\text { Posttest Kelas Eksperimen dan } \\
\text { Kelas Kontrol }\end{array}$ & 0,000 & 0,025 & $\mathrm{H}_{1}$ diterima \\
\hline
\end{tabular}

Berdasarkan Tabel 4. diperoleh data pretest kelas eksperimen dan kelas kontrol sebesar 0,172 yang artinya $\mathrm{H}_{0}$ diterima (sig.(2-tailed) $\left.>0,172>0,025\right)$, pada data posttest kelas eksperimen dan kelas kontrol sebesar 0,000 yang artinya $\mathrm{H}_{1}$ diterima (sig.(2-tailed) < $0,000<0,025)$. Kesimpulannya untuk data pretest tidak terdapat pengaruh yang signifikan penggunaan metode pembelajaran terhadap hasil belajar siswa pada materi sistem peredaran darah manusia kelas VIII SMP N 3 Silat Hilir, sedangkan untuk data posttest terdapat pengaruh yang signifikan penggunaan metode pembelajaran terhadap hasil belajar siswa pada materi sistem peredaran darah manusia di kelas VIII SMP N 3 Silat Hilir.

Berdasarkan Tabel 4. diperoleh data pretest-posttest kelas eksperimen sebesar 0,000 yang artinya $\mathrm{H}_{1}$ diterima (sig.(2-tailed) < a 0,000 <0,025), pada data pretest-posttest kelas kontrol sebesar 0,000 yang artinya $\mathrm{H}_{1}$ diterima (sig.(2-tailed) $<\mathrm{a} 0,000<0,025$ ). Kesimpulannya untuk data pretest-postest terdapat perbedaan yang signifikan penggunaan metode Guided Note Taking berbantuan media gambar terhadap hasil belajar siswa pada materi sistem peredaran darah manusia kelas VIII SMP N 3 Silat Hilir, sedangkan untuk data pretest-posttest terdapat perbedaan yang signifikan penggunaan metode konvensional 
terhadap hasil belajar siswa pada materi sistem peredaran darah manusia kelas VIII SMP N 3 Silat Hilir.

Tabel .4. Uji Hipotesis Paired Samples Test

\begin{tabular}{lllll}
\hline Kelas & Jenis Test & Sig. (2-Tailed) & a & Kesimpulan \\
\hline Eksperimen & Pretest-Posttest & 0,000 & 0,025 & $\mathrm{H}_{1}$ diterima \\
\hline Kontrol & Pretest- Posttest & 0,000 & 0,025 & $\mathrm{H}_{1}$ diterima \\
\hline
\end{tabular}

\section{PEMBAHASAN}

Hasil belajar siswa dalam penelitian ini terlihat dari hasil analisis ujihipotesis pada pengukuran akhir (posttest), yang di analisis menggunakan SPSS statistics 23.0. Berdasarkan hasil analisis diperoleh hasil posttest siswa kelas eksperimen dan kelas kontrol mengalami perbedaan.

Hasil yang diperoleh siswa kelas eksperimen dengan nilai tertinggi 100 dengan nilai terendah 55 dan rata-rata 74,21, sedangkan hasil yang diperoleh kelas kontrol dengan nilai tertinggi 85 dengan nilai terendah 50 dan rata-rata 64,52. Setelah di peroleh data hasil posttest kelas eksperimen dan kelas kontrol maka selanjutnya dilakukan uji hipotesis

Hasil uji hipotesis menunjukan bahwa nilai sig.(2-tailed) $<$ a yakni 0,000 $<0,05$ artinya terdapat perbedaan antara nilai rata-rata posttest kelas eksperimen dan kelas kontrol.Hal ini sejalan dengan penelitian yang dilakukan oleh Ghozali (2013) dengan judul penelitian 'Peningkatan Hasil Belajar Biologi Melalui Penerapan Strategi Pembelajaran Guide Note Taking Pada Materi Sistem Peredaran Darah Manusia Kelas VIII Smp Negeri 2 Gatak SukoharjoTahun Ajaran 2012/2013 yang menyatakan bahwa Hasil belajar siswa pada prasiklus dengan KKM 70 rata-rata kognitifnya 67 dengan prosentase ketuntasan $41 \%$ siswa yang sudah mencapai KKM 70, dan siswa yang belum mencapai KKM 59\% siswa. Hasil belajar pada siklus satu telah mengalami peningkatan nilai rata-rata 73 dengan prosentase ketuntasan $71 \%$ siswa telah mencapai KKM dan siswa yang belum mencapai KKM 29\% siswa. Dalam penelitian ini pada siklus satu telah mengalami peningkatan yang baik, jadi tidak perlu diadakan penelitian lanjut (siklus II). Jadi dapat disimpulkan bahwa penerapan strategi Guide Note taking dapat meningkatkan hasil belajar siswa kelas VIII SMP Negeri 2 Gatak Sukoharjo pada materi sistem peredaran darah pada manusia. Hasil penelitian sebelumnya yang dilakukan oleh IIma (2011) bahwa penerapan model pembelajaran Guided Note Taking (GNT) dapat meningkatkan aktivitas dan hasil belajar siswa. Aktivitas belajar siswa dengan menggunakan model pembelajaran Guided Note Taking (GNT) semakin meningkat. Hal ini terbukti saat selama proses pembelajaran siswa yang biasanya takut mengeluarkan pendapat menjadi berani dan siswa yang tidak mau bekerjasama menjadi mau. Hasil belajar rata-rata kelas peningkatan sebesar $50,74 \%$.

Hasil uji hipotesis menunjukan bahwa Ha dapat diterima yaitu terdapat pengaruh yang signifikan metode guided note taking berbantuan media gambar terhadap hasil belajar siswa pada materi sistem peredaran darah pada manusia di kelas VIII SMP Negeri 3 Silat Hilir.

\section{SIMPULAN}

Berdasarkan pada hasil analisis dalam penelitian ini, secara keseluruhan dapat disimpulkan bahwa metode guided note taking berbantuan media ganbar berpengaruh secara signifikan terhadap hasil belajar siswa kelas VIII materi sistem peredaran darah pada manusia. Secara terperinci hasil penelitian ini dapat disimpulkan sebagai berikut:

1. Proses pembelajaran menggunakan metode guided note taking berbantuan media gambardi kelas VIII C sekolah menengah pertama negeri 3 silat hilir sebagai kelas eksperimen Berjalan dengan baik. Rata-rata persentase pertemuan pertama dan kedua sebesar $100 \%$ berkriteria “ 
2. Tidak terdapat perbedaan yang signifikan hasil pretest pada kelas eksperimen dan kelas kontrol terhadap hasil belajar kognitif siswa materi sistem peredaran darah pada manusia dikelas VIII SMP Negeri 3 Silat Hilir, dimana diperoleh nilai rata-rata pretest kelas eksperimen 31,32 dengan kategori "Kurang", dan nilai rata-rata pretest kelas kontrol diperoleh 36,19 dengan kategori "Kurang", Selain itu hasil analisis diperoleh Sig (2-tailed) $>0,025$ yakni $0,172>0,025$.

3. Terdapat perbedaan yang signifikan hasil posttest pada kelas eksperimen dan kelas kontrol terhadap hasil belajar kognitif siswa materi sistem peredaran darah pada manusia dikelas VIII SMP Negeri 3 Silat Hilir, dimana diperoleh nilai rata-rata posttest kelas eksperimen 78,16 dengan kategori "Baik" dan nilai rata-rata posttest kelas kontrol diperoleh 64,52 dengan kategor "Baik", Selain itu hasil analisis diperoleh Sig (2-tailed) < 0,025 yakni $0,000<0,025$.

4. Terdapat pengaruh yang signifikan metode guided note taking berbantuan media gambar terhadap hasil belajar siswa materi sistem peredaran darah dengan hasil analisis diperoleh sig. (2-tailed) $<0,025$ yakni $0,000<0,025$

5. Terdapat pengaruh yang signifikan metode guided note taking berbantuan media gambar terhadap hasil belajar siswa materi sistem peredaran darah dengan hasil analisis diperoleh sig. (2-tailed) $<0,025$ yakni 0,000 < 0,025

6. Respon siswa terhadap metode guided note taking secara keseluruhan sebesar $65,79 \%$, berdasarkan rentang penilaian angket maka termasuk ke dalam kriteria respon yang baik.

\section{REFERENSI}

Agung, A. A. Gede. (2011). Metodologi Penelitian Pendidikan. Singaraja:Undiksha.

Amri, S. 2013. Pengembangan dan Model Pembelajaran dalam Kurikulum 2013. Jakarta: Prestasi Pustaka.

Anwar, M. S. (2017). Pengaruh Pembelajaran Lesson Studi Terhadap Hasil Belajar Kognitif Siswa pada Materi Ciri-Ciri Makhluk Hidup Kelas VIII SMP Negeri 1 Ketungau Tengah ".Skripsi tidak diterbitkan. Sintang: STKIP Persada Khatulistiwa Sintang

Aprizaiyanti, R. (2017) "Penerapan model Discovery StrategyTerhadap Berpikir Kreatif Siswa Pada Pokok Bahasan Pertumbuhan Dan Perkembangan Di Kelas Viii SmpNegeri 4 Sayan". Skripsi tidak diterbitkan. Sintang: STKIP Persada Khatulistiwa Sintang.

Arikunto, S. (2010). Prosedur Penelitian Suatu Pendekatan Prakmatik. Yogyakarta:Rineka Cipta.

Sudjana, N. (2009). Penilaian Hasil Proses Belajar Mengajar. Bandung: Remaja Rosdakarya.

Karim, S. dkk. (2008). IPA Terpadu Untuk SMP/MTs Kelas VIII. Jakarta: Pusat Perbukuan, Departemen Pendidikan Nasional

Hamalik, O. (2008). Perencanaan Pengajaran Berdasarkan Pendekatan Sistem. Jakarta, Bumi Aksara.

Hasanah, Z. (2015). "Pengaruh Metode Pembelajaran Guided Note Taking terhadap Hasil Belajar Siswa Kelas VIII SMP Negeri 2 Belimbing pada Pokok Bahasan Pertumbuhan 
Dan Perkembangan Makhluk Hidup ".Skripsi tidak diterbitkan. Sintang: STKIP Persada Khatulistiwa Sintang. 